\title{
Lær Dansk på Nettet!
}

\author{
Karen M. Lauridsen \\ Lektor, cand.mag. \\ Institut for Sprog og Erhvervskommunikation \\ Aarhus School of Business \\ kml@asb.dk \\ http://www.asb.dk/staff/isek/kml.aspx
}

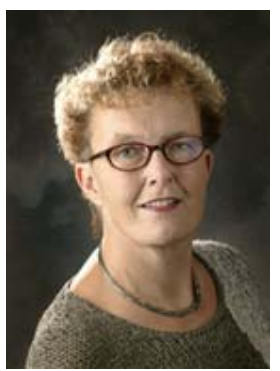

Karen M. Lauridsen har været projektkoordinator på NetDansk der som partnere havde eksperter inden for dansk som fremmedsprog, fremmedsprogspcedagogik og e-læering. Karen M. Lauridsen har selv en lingvistisk baggrund, men hendes bidrag var her primert kendskab til målgruppen via hendes erfaring med internationalisering af højere uddannelse samt projektstyring.

Karen M. Lauridsen er tilknyttet forskergruppen NEBERU (virksomhedens ikke-økonomiske omgivelser); hun underviser primcert på de engelsksprogede uddannelser inden for områderne kommunikation, $P R$, medier og informationsarbejde på ASB.

\section{Indledning}

NetDansk ${ }^{1}$ er et danskkursus rettet mod studerende og andre yngre akademikere der kommer til Danmark for at studere eller arbejde. Den første version, som bliver beskrevet nedenfor, er resultatet af et Socrates/Lingua Aktion 2 projekt $^{2}$ (2002-2005).

\section{Læringsmål}

NetDansk har som målsætning at den lærende har kompetencer i dansk svarende til niveau A1 i Europarådets fælles referenceramme for sprog ved afslutningen af den første del (NetDansk 1; se nedenfor), og at den lærende har opnået kompetencer svarende til niveau A2 når vedkommende har arbejdet med udvalgte dele af NetDansk 2. En væsentlig forudsætning for at den lærende opnår disse kompetencer, er at vedkommende arbejder med stoffet både før og efter ankomsten til Danmark. NetDansk lægger således grunden for at den lærende kan videreudvikle sine kompetencer på niveau B under et længerevarende ophold i landet, og her kan NetDansk 2 fortsat støtte indlæringen.

\subsection{Europarådets fælles referenceramme for sprogniveauer}

Europarådets fælles referenceramme ${ }^{3}$ er opdelt i seks niveauer. Det er hensigten at den lærende skal have udviklet følgende kompetencer for at kunne siges at være på niveau A2, her gengivet efter den danske oversættelse af selvevalueringsskemaet i en sprogportfolio: ${ }^{4}$

Jeg kan forstå enkle sætninger og de almindeligste ord når det drejer sig om ting der er vigtige for mig (fx helt enkle informationer om mig selv, min familie, mit arbejde eller mine omgivelser). Jeg forstår det væsentligste indhold i korte, klare og enkle meddelelser. Jeg kan læse helt korte og enkle tekster. Jeg kan finde konkret, forudsigelig information i enkle hverdagstekster (fx annoncer, brochurer, spisekort, køreplaner), og jeg kan forstå korte personlige breve. Jeg kan gøre mig forståelig i ukomplicerede rutineprægede situationer hvor det drejer sig om enkel og direkte udveksling af information og emner eller aktiviteter jeg kender på forhånd. Jeg kan føre en meget 
kort, dagligdags samtale med andre, men jeg forstår normalt ikke nok til selv at holde samtalen i gang. Jeg kan i flere sætninger og med enkle midler fortælle om $\mathrm{fx}$ min familie, andre mennesker, min boligsituation, min uddannelse, mit job. Jeg kan skrive korte og enkle meddelelser og notater. Jeg kan skrive et helt enkelt personligt brev, fx et takkebrev.

\section{Indhold og målgruppe}

Der er en lille gruppe af gennemgående personer i historierne og dialogerne. Ligesom NetDansks primære målgruppe er det unge mennesker der studerer eller er i gang med at skabe sig en karriere. Indholdet og de situationer som disse unge mennesker befinder sig i, vil derfor være velkendte for dem som skal lære dansk via NetDansk. Hertil kommer at der er information om Danmark, dansk kultur og dagligliv i landet. Specielt NetDansk 2 indeholder en ikke ubetydelig mængde information både i infoteksterne og i dialogerne.

Det tages for givet, at de lærende har en akademisk baggrund og er vant til at studere og lære på egen hånd. Det forventes derfor også at de er vant til at arbejde med it og til at arbejde med standardsoftware på internettet. Dette har betydning både for materialets indhold og form og for den måde det bliver præsenteret på. Der er tale om en hurtig progression da materialet er målrettet til en veluddannet og højt motiveret gruppe af mennesker.

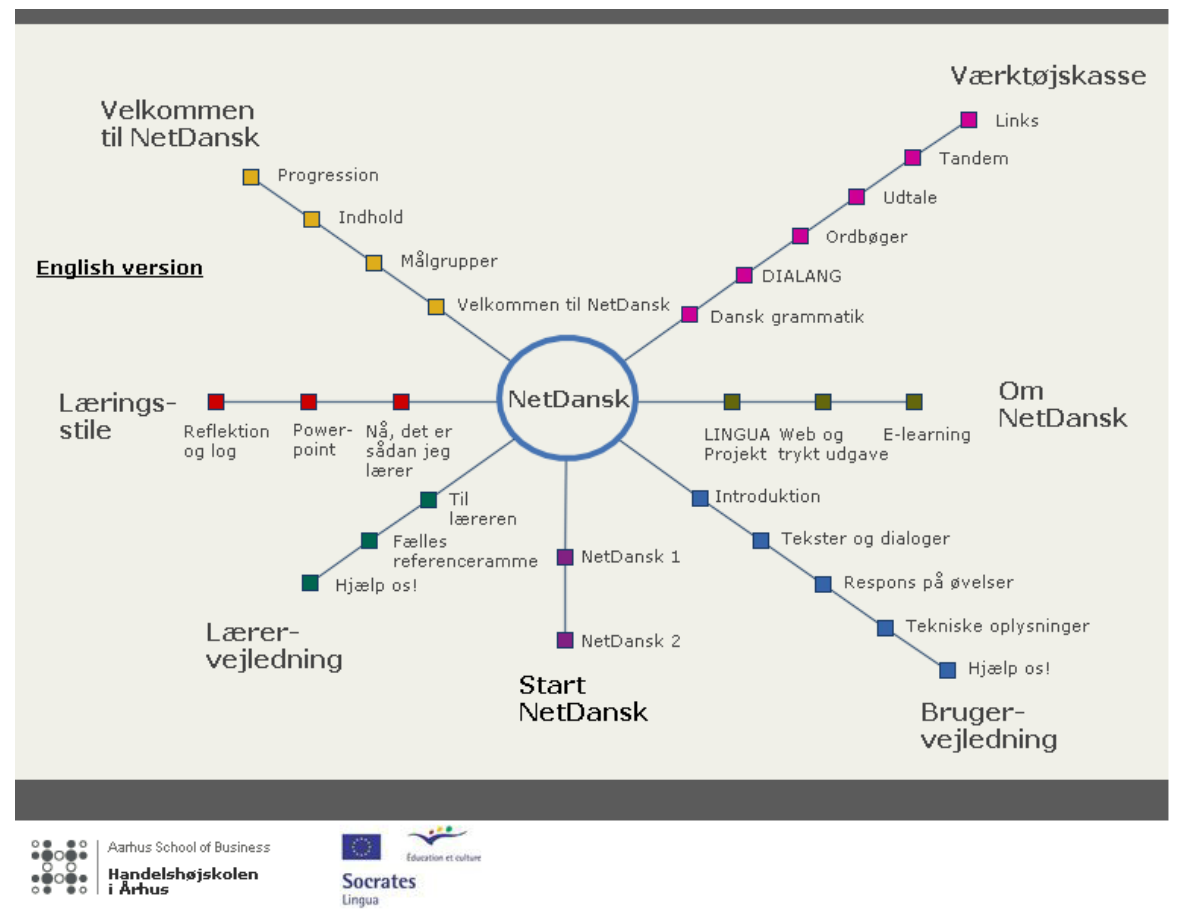

Fig. 1 Forsiden på NetDansk (www.netdansk.net)

NetDansk er delt i NetDansk 1 og NetDansk 2. NetDansk 1 dækker grundlæggende dansk grammatik og ordforråd på 17 metrolinjer (kapitler). Disse 17 linjer har stationer med tekster, dialoger og øvelser. Der er en klar progression fra linje 1 (intet kendskab til dansk) og til linje 17. Webversionen har lydfiler (tekster og dialoger); den er beregnet til individuel læring (selvstændigt arbejde og e-læring) og som supplement til mere traditionel klasseundervisning. 
NetDansk 1 indeholder også mindre sektioner om Danmark. Dette udvikles yderligere i NetDansk 2. Ud over webversionen er der en trykt udgave af NetDansk 1 der primært er beregnet til klasseundervisning. ${ }^{5}$ De to udgaver af NetDansk 1 (webversionen og den trykte udgave) kan bruges sammen. Deltagerne i klasseundervisning kan således arbejde med webversionen som supplement til det der forgår i klassen.

Det er forudsat at NetDansk 1 har en samlet arbejdsbelastning for lærende i den primære målgruppe på maksimalt 3 ECTS. Det er derfor velegnet til relativt korte sprogkurser for udenlandske studerende før eller i begyndelsen af deres første semester i Danmark. I denne sammenhæng muliggør webversionen at de studerende kan forberede sig hjemmefra. Al erfaring viser at det styrker hurtig indlæring efter at de er kommet til Danmark.

NetDansk 2 er beregnet for dem der har afsluttet NetDansk 1 og er kommet til Danmark eller er på vej til Danmark. NetDansk 2 der omfatter 28 metrolinjer, kan være en stor udfordring for den studerende. Der er ikke en egentlig progression i materialet; i stedet dækker det en række forskellige situationer som er relevante for målgruppen, og som indeholder yderligere informationer om dagligliv i Danmark, dansk kultur og traditioner samt praktiske informationer (offentlig transport, at bo på kollegium, at gå til læge, osv.). NetDansk 2 opfordrer dermed de studerende til at blive ved med at udvikle deres sproglige og interkulturelle færdigheder både før og efter de er kommet til Danmark. Hver linje er koncentreret om et bestemt emne, og det er så op til de studerende at vælge det der er mest relevant eller interessant for dem. NetDansk 2 findes udelukkende i webudgaven.

Med skyldigt hensyn til målgruppen er NetDansk som helhed karakteriseret ved

- hurtig progression,

- stadig gentagelse af ordforråd og grammatik,

- længere tekster introduceres relativt tidligt,

- anvendelse af kvalificerede gæt der bliver hjulpet på vej af genkendelige og/eller internationale ord,

- den samme gruppe af unge mennesker i teksterne og dialogerne,

- moderne (neutralt) sprog,

- tekster med et indhold (fx præsentation af dagligliv i Danmark),

- induktiv metode - kursusdeltagerne bliver opfordret til at udlede grammatiske regler af materialet,

- $\quad$ en interkulturel dimension - fx dagligliv i Danmark, hvordan studerende bor, hvad de laver i deres fritid, hvad de spiser, osv.

Webudgaven af NetDansk

- er beregnet til selvstudium,

- har varierede øvelser,

- giver mulighed for at gentage øvelser hvis eller når man har behov for det,

- anvender en kombination af lyd, tekst og billeder,

- træner lytteforståelse, udtale, læseforståelse, skriftlig produktion og ordforråd,

- omfatter kommunikative øvelser (tale og skrift) hvor det er muligt,

- kan bruges til at differentiere mellem elever på forskelligt niveau i klassen, 
- fremmer viden om Danmark (befolkningen, kultur og traditioner, information om dagligliv, specielt for unge mennesker).

\section{Selvstændig læring og læringsstile}

I tillæg til det egentlige kursusmateriale er der en række infomations- og støttefunktioner i webudgaven. Da e-læring jo ofte netop er karakteriseret ved at lægge op til selvstændigt arbejde uden en underviser, er der lagt vægt på at introducere de lærende til selvstændig læring og læringsstile, først og fremmest for at de bliver opmærksomme på hvor meget det kræver at arbejde alene med helt nyt stof og udvikling af helt nye færdigheder.

For at lære mest effektivt skal den lærende have vilje og evne til at arbejde selvstændigt og være i stand til at træffe afgørelser om sig selv, have mulighed for at arbejde selvstændigt, deltage aktivt i læreprocessen, have vilje og evne til at ændre sig, kunne reflektere over, hvad han eller hun foretager sig, have indsigt i sin egen læringsstilsprofil.

Selvstændigt arbejde er alfa og omega i al læring. Et menneske husker information alt efter hvordan han eller hun har optaget den; man husker

- $10 \%$ af det man læser,

- $20 \%$ af det man hører,

- $30 \%$ af det man ser,

- $70 \%$ af det man ser og hører,

- $90 \%$ af det man er aktivt involveret i.

Der er således god grund til at antage at den lærende kan få særdeles meget ud af at arbejde alene med webudgaven af NetDansk hvis vedkommende både har en høj grad af motivation fordi vedkommende er på vej til at studere eller arbejde i Danmark (den primære målgruppe), er akademisk uddannet og vant til eller indstillet på at arbejde målrettet og selvstændigt.

\subsection{Refleksion}

I tilknytning til en introduktion til selvstændigt arbejde i webudgaven, er der en metrolinje om Læringsstile og refleksion (jf. fig. 1 ovenfor). På metrostationen Refleksion og log får den lærende et kort introduktion til refleksion samt et skema til at skrive

- Proceslog for at samle materiale om en proces og reflektere over observationerne (Hvad skete der? Hvad følte jeg? Hvad lærte jeg?).

- Meta-kognitiv log for at skabe bevidsthed om hvordan læring finder sted (Hvad skete der? Hvad lærte jeg? Hvordan lærte jeg det?).

- Prognoselog for at evaluere om projektforventningerne vil blive opfyldt (Hvad skete der? Hvad kan der ske i fremtiden på basis af hvad der er sket? Hvorfor?).

- Synteselog for at lære en metode til at få overblik over hvad der er sket og relatere det til fremtiden (Hvad gjorde jeg? Hvad lærte jeg? Hvordan kan jeg bruge det?).

- Kommunikativ log for at lære en metode til at indgå i skriftlig dialog (Hvad gjorde jeg? Hvad vil jeg gerne diskutere? Mine kommentarer). 


\subsection{Læringsstile}

Metrolinjen indeholder også en introduktion til læringsstile i overensstemmelse med Dunn og Dunns ${ }^{6}$ koncept. Læringsstile er den måde den enkelte koncentrerer sig om nyt og vanskeligt stof på, den måde han eller hun optager, bearbejder og senere husker det på. Modellen indbefatter altså hele læreprocessen og ikke kun dele af den sådan som det er tilfældet i langt de fleste øvrige teorier om læringsstil.

Dunn \& Dunns model opererer med 5 typer af stimuli: læringsmiljøet, de emotionelle, sociale, fysiologiske og psykologiske stimuli med i alt 21 elementer eller præferencer.

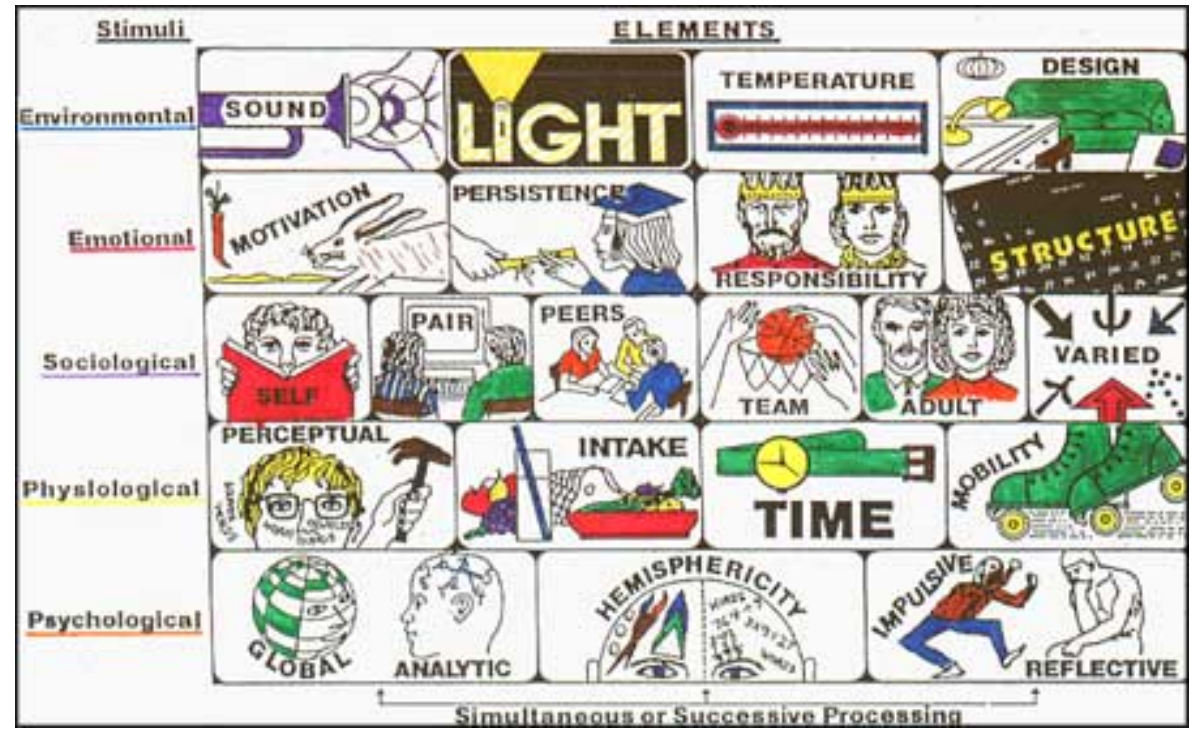

Fig. 2 De 21 elementer i Dunn \& Dunns læringsstilskoncept ${ }^{7}$

Alle mennesker har mellem 6 og 14 præferencer i deres læringsstilsprofil. På metrolinjen er der en kort introduktion til læringsstil samt et link til den amerikanske Building Excellence ${ }^{8}$ test som den enkelte kan gennemgå for at få diagnosticeret sin personlige læringsstilsprofil. I 2006 bliver Building Excellence testen også tilgængelig på dansk.

Dunns og Dunns model er baseret på omfattende forskning og er blevet evalueret i utallige sammenhænge på alle niveauer i uddannelsessystemet. Den tager hensyn til alle hjernens centrale læringssystemer, og den tvinger i modsætning til andre læringsstilsteorier ikke de lærende til at bruge stile, der er dem fremmede og imod. Tvinges folk til at lære på en anden måde end den der passer dem, hæmmes deres læring.

\subsection{Læringsstile i NetDansk}

Læringsstile er blevet indtænkt i NetDansk. Ud over at den lærende har alle muligheder for at arbejde selvstændigt, kan vedkommende også drage nytte af den overordnede struktur og det overordnede layout der tilgodeser både analytisk og globalt lærende.

Metrokonceptet som er gennemført i hele webudgaven, er beregnet til at understøtte forskellige læringsstilspræferencer. NetDansk 1 og 2 er præsenteret som to metrolinjer, og hvert kapitel er en station på en metrolinie (NetDansk 1 eller 2), og samtidig er det en ny metrolinje. Man kan således få et overblik over kapitlerne (metroens linjer og stationer), eller man kan gå frem skridt for skridt 
hvis det er det man foretrækker. Når man standser ved en bestemt station, kan man vælge at se al information på en gang ved at scrolle ned over siden før man tager fat på enkeltdelene, men man kan også gå trinvis frem.

Endelig skulle de farver der er valgt, være så neutrale, at alle kan lide dem - men samtidig er de sådan sammensat, at også den globalt lærende vil føle sig stimuleret.

\section{Værktøjskasse og brugervejledninger}

Som det fremgår af fig. 1 ovenfor, er webudgaven af NetDansk forsynet med såvel en værktøjskasse som vejledninger for både lærere og lærende. Lærervejledningen indeholder fx en introduktion til Europarådets fælles referenceramme for den underviser som ikke kender den i forvejen. Brugervejledningen til den lærende indeholder en kort vejledning i hvordan man kan arbejde med stoffet på de enkelte metrostationer (kapitler) samt de nødvendige tekniske informationer.

Værktøjskassen indeholder for det første henvisninger til en lille dansk grammatik, til ordbøger og til en lille funktion ${ }^{9}$ som hurtigt kan give den lærende udtalen på enkeltord eller korte sætninger.

Endvidere er der et link til DIALANG ${ }^{10}$, det europæiske testsystem hvor den enkelte gratis kan teste sine kompetencer på fjorten forskellige sprog, herunder dansk. Når man afslutter testen, får man feedback i overensstemmelse med niveauerne i den fælles europæiske referenceramme; man kan således eksempelvis få feedback der viser at man på receptionssiden (læse og lytte) har opnået en kompetence på niveau A1, men at det ikke gælder på produktionssiden. DIALANG tester for grammatik og ordforråd samt skriftligt input (den lærendes produktion), men man kan ikke teste talt sprog og dialog. Alligevel kan de diagnostiske tests i DIALANG være et godt værktøj til at måle progressionen i indlæringen for den enkelte.

Endelig har Værktøjskassen henvisning til Tandem og andre relevante links for den som interesserer sig for at lære fremmedsprog og få adgang til elektroniske læringsressourcer.

\section{Afsluttende bemærkninger}

Som det fremgår ovenfor, er NetDansk blevet udviklet med en klart defineret målgruppe for øje, og dette har på helt centrale punkter været afgørende for danskkursets indhold og form. Samtidig har det været en klar målsætning med udviklingsprojektet at det skulle tage hensyn til det (relativt) nye medie og dets muligheder og begrænsninger. Selvstændig læring via Internettet er ikke blot det samme som at sætte strøm på et traditionelt, klassebaseret kursus.

De første erfaringer tyder på at det er lykkedes et stykke af vejen, men at der også er elementer i kurset som kan forbedres. På Aarhus School of Business / Handelshøjskolen i Århus er det vores hensigt at revidere materialet i løbet af 2006 samtidig med at vi forbereder en endelig udgave af den trykte version i samarbejde med vores projektpartnere.

\footnotetext{
${ }^{1}$ www.netdansk.net

${ }^{2}$ Samarbejdspartnerne var Sproghøjskolen på Kalø (nu Europahøjskolen på Kalø); Aarhus Universitet; Jyväskylan Yliopisto, Finland; University of Limerick (Irland); Université de Lausanne (Schweiz); La Sapienza Roma (Italien); Videnscenter for Integration, Vejle; International Tech, Odense.
} 
${ }^{3}$ http://www.coe.int/T/E/Cultural_Co-

operation/education/Languages/Language_Policy/Common_Framework_of_Reference/index.asp\#TopOfPage

${ }^{4}$ Her gengivet efter den danske oversættelse af selvevalueringsskemaet i referencerammen, jf. http://www.sprog.asb.dk/OL/ELP/5\%20Eksempler\%20(Beispiele)/1Skema_til_selvevaluering.pdf

${ }^{5}$ Når den oprindelige udgave er blevet revideret medio 2006, vil NetDansk 1 blive (forhåbentlig) blive udgivet på et dansk forlag.

${ }^{6}$ www.learningstyles.org

${ }^{7}$ Jf. http://www.learningstyles.net/2004/1_ls_model.html

${ }^{8}$ www.building-excellence.com

${ }^{9}$ Adgang for alle der er udviklet på Aalborg Universitet: www.adgangforalle.dk

${ }^{10}$ www.dialang.org 